\title{
Validation of a Measure of Service Climate in Organizations
}

\section{Validación de una Medida de Clima de Servicio en las Organizaciones}

\author{
Hugo Carrasco, Vicente Martínez-Tur, José M. Peiró, and Carolina Moliner \\ IDOCAL, University of Valencia
}

\begin{abstract}
Service climate is critical for organizations pertaining to the service sector. It reflects the importance organizations attribute to service quality and efforts to please customers. Using previous work of Schneider, White, and Paul (1998) as starting point, this research validates a measure of service climate in the Spanish language. Data from two survey study projects were brought together. A total of 120 hotels, located in Spain, participated in the research. The sample consisted of 508 frontline hotel employees distributed in 152 work-units. Our results confirmed that construct and predictive validity are satisfactory, with four factors describing the facets of service climate: Global Service Climate, Customer Feedback, Customer Orientation, and Managerial Practices. Findings support the idea that frontline employees pertaining to the same work-unit are able to develop shared perceptions of service climate beyond individual differences. The scale is confirmed as a good measure of service climate in the Spanish context. Keywords: construct validity, predictive validity service climate, shared perceptions.
\end{abstract}

Resumen. El Clima de Servicio resulta crítico en organizaciones del sector servicios. Refleja la importancia que las organizaciones atribuyen a la calidad del servicio así como los esfuerzos para complacer a los clientes. Considerando el trabajo de Schneider, White y Paul (1998) como punto de partida, este trabajo valida una medida del clima de servicio en español. Para ello se han desarrollado dos estudios de campo. Un total de 120 hoteles, ubicados en España, participaron en la investigación. La muestra estuvo conformada por 508 empleados de hoteles distribuidos en 152 unidades de trabajo. Nuestros resultados confirmaron que la validez de constructo y predictiva son satisfactorias, con cuatro factores que limitan la descripción de las facetas del clima de servicio: Servicio Global del Clima, Comentarios del cliente, orientación al cliente, y prácticas de gestión. Los resultados apoyan que los empleados de primera línea pertenecientes a la misma unidad de trabajo son capaces de desarrollar percepciones compartidas de clima servicio más allá de las diferencias individuales. La escala se confirma como una buena medida del clima de servicio en el contexto español.

Palabras clave: validez de constructo, validez predictiva, clima de servicio, percepciones compartidas.

The "cognitive revolution", which describes one of the characteristics of the evolution in psychology during the XX century, introduces human cognition between environmental stimuli and human responses through the psychological meaning that the environment has for individuals. There have been two classic contributions to understanding "meanings" in psychology. First, in "The measurement of meaning" by Osgood, Suci, and Tannenbaum (1957), the authors identified concepts used spontaneously by individuals to describe objects from the environment in relation to themselves, producing the well-known dimensions of evaluation, potency, and activity. These dimensions are part of the single dimension of evaluation for affectively-loaded objects (Osgood et al., 1957). Accordingly, individuals attribute meanings by indicating the "goodness" or "badness" of the object. Second, based on the previous work by Jones and James (1979),

Correspondence concerning this article should be addressed to José M. Peiró, Facultad de Psicología, Av. Blasco Ibáñez, 21. 46010, E.mail: jose.m.peiro@uv.es
James, James, and Ashe (1990) emphasized psychological constructs, such as ambiguity, challenge, loyalty, cooperation, equity, rationality and support, to interpret environmental objects and elements, while avoiding the evaluation of their goodness and badness directly. Both of these perspectives are probably needed to fully understand the concept of "meaning". The attribution of meaning to external stimuli refers to the process of using previously stored mental representations to interpret sensory information (Shaver, 1987). This process involves the evaluation of the "goodness" and "badness" of the object, but also specific perceptions of facets of the external reality.

This interest in the role of the cognitive interpretation of stimuli was extended to the different contexts of human life, including organizations. In their influential work, James and Jones (1974) used "psychological climate" and "organizational climate" to refer to the meanings workers and work groups assign to their own jobs, co-workers, supervisors, pay, performance expectations, etc. The climate concept facilitates the definition and measurement of workers' and groups'in- 
terpretations of organizational environment. The meanings imputed to environmental work attributes are phenomenological experiences, that is, cognitive constructions designed to interpret information sensed from the work and organizational environment (see James et al., 2008 for a review).

During the last few decades, interest in the investigation of climate in organizations has increased considerably. Scholars have invested their energy in different directions. One of the areas of interest is the study of specific climates. It is assumed that important facets of organizational life create specific organizational climates (Dietz, Pugh, \& Whiley, 2004). Multiple climates exist within organizations (Schneider, White, \& Paul, 1998), and their evaluation makes it possible to obtain stronger relationships with specific organizational outcomes (e.g., safety, service) than those obtained from general definitions and assessments of climate (Schneider, Wheeler, \& Cox, 1992).

In the service sector, a critical specific climate is the "service climate", which refers to "employee perceptions of the practices, procedures and behaviors that get rewarded, supported, and expected with regard to customer service and customer service quality" (Schneider et al., 1998, p. 151). When service climate exists, efforts related to customer service are reinforced by organizations. The measurement of service climate is important in the service sector because it has a significant impact on critical outcomes such as customer perceptions of service quality (e.g., MartínezTur, Tordera, Peiró, \& Potocnik, 2011; Salanova, Agut \& Peiró, 2005; Schneider, Ehrhart, Mayer, Saltz, \& Niles-Jolly, 2005).

Schneider and colleagues (Schneider et al., 1998; Schneider, Salvaggio, \& Subirats, 2002) designed a well-known measure of service climate which was developed in the USA. Using their research as a starting point, the present study aims to describe and validate a measure of service climate in the Spanish language. The contributions of this research are two-fold. First, although the aforementioned service climate measure is well-recognized in the literature, further research is needed to examine its validity, especially because the measure is written in a different language and used in another cultural context. To this end, its construct and predictive validity were examined. Second, we explored the levels of the construct of service climate using this measure. In addition to individual differences in the interpretation of service climate (psychological climate), it is generally assumed that employees are able to develop shared perceptions (e.g., Hui, Chiu, Yu, Cheng, \& Tse, 2007; Salanova et al., 2005), describing a collective reality beyond the individual level (organizational climate). Accordingly, we investigated whether this measure of service climate can be aggregated at the work-unit level. All of these endeavours offer a detailed picture to evaluate the construct and predictive validity of a measure of service climate in the Spanish language.

\section{Theoretical Background}

\section{Climate in Organizations}

The evolution of climate study has its roots in Lewin's studies of experimentally-created social climates (Lewin, 1951; Lewin, Lippit, \& White, 1939) and in qualitative observation of natural organizational settings (Barker, 1965; Likert, 1961). Furthermore, climate's first appearance as a topic of study within the field of organizational studies can be observed in two books. The first book Organizational climate: Explorations of a concept, by Tagiuriand Litwin (1968), presented a wide variety of approaches, ranging from perspectives that conceptualize climate as an "objective" set of organizational conditions to those that view climate as a "subjective interpretation" of individual and organizational characteristics. The second book, Motivation and organizational climate, by Litwin and Stringer (1968), focused on consequences of organizational climate for individual motivation, supporting the idea that climate encompasses both organizational conditions and individual reactions. In addition to these two books, Likert $(1961,1967)$ and Campbell, Dunnette, Lawler, and Weick (1970) contributed to the literature by defining sets of dimensions representing the most important aspects of organizational climate. Later, interest in climate focused on its integration with the field of organizational studies. Review articles published in the 1970s (Hellriegel \& Slocum, 1974; James \& Jones, 1974; Payne \& Pugh, 1976) established three different approaches to climate study: the perceptual measurement of individual attributes (psychological climate), the perceptual measurement of organizational attributes (organizational climate), and the multiple measurement of organizational attributes by combining perceptual and "objective" measures (Denison, 1996).

Climate research has been carried out extensively in the context of organizations, with an important number of articles in scientific journals. Research efforts have demonstrated the important predictive power of climate in organizations. Climate maintains significant relationships with outcomes such as performance (see Ashkanasy, Wilderom, \& Peterson, 2000 for a review) and innovation (Rousseau, 1988). These research studies focused on general or molar conceptions of climate. In fact, the Tagiuri and Litwin (1968) classic definition of climate describes it as a quality of the organizational environment as a whole. However, several researchers argued that the predictive power of organizational climate can be improved with the definition and measurement of specific climates more strongly connected to specific outcomes (Schneider et al., 1992). Looking into specific climates might provide relevant knowledge (Wiley, 1996) for specific occupations/sectors and outcomes of interest (Day \& Bedeian, 1995). One of these specific climates is "service climate". 


\section{Service Climate}

The first research on service climate was conducted by Schneider (1973), focusing the attention on the degree to which organizations create a "warm and friendly atmosphere" for their customers. Customers of bank services were interviewed in order to obtain input for an instrument to define and measure this atmosphere. However, these interviews revealed that customers described not only interpersonal issues, but also facets of the work environment, such as equipment, turnover, and others. With this in mind, Schneider hypothesized that employees have similar sets of experiences related to services, and, accordingly, employee and customer experiences should be correlated. Thus, service climate created for employees would be related to employees' behaviour; in turn, this behaviour should influence the service climate experienced by customers (Schneider, Bowen, Ehrhart, \& Holcombe, 2000). Schneider and colleagues continued this effort by documenting the relationship between employee experiences of service climate and customer experiences of service climate and service quality (Parkington \& Schneider, 1979; Schneider, 1980; Schneider \& Bowen, 1985). The investigation of this connection between employee and customer perceptions is generally known as linkage research. The logic behind this idea is that what happens internally in an organization, with regard to creating and supporting a quality customer service environment, influences the behaviour of employees in their interactions with customers, which finally yields the service quality perceived by customers (Schneider et al., 2002).

Service climate has been shown to be a relevant variable for organizations. Research has observed that service climate is associated with customer perceptions of service quality (Dietz et al., 2004; Johnson, 1996; Schneider \& Bowen, 1995; Wiley, 1996) and customer satisfaction (Martínez-Tur et al., 2011). Moreover, significant longitudinal relationships have been found between service climate and customer perceptions of service quality (Schneider et al., 1998). Wiley (1996) found significant direct relationships between specific service climate dimensions (customer orientation) and financial results. Similarly, service climate was significantly related to positive job-related attitudes toward increased sales (Leung, 1997) and revenue growth (Rucci, Kirn, \& Quinn, 1998). Borucki and Burke (1999) found that service climate was predictive of employee service performance, and this performance, in turn, predicted stores' financial outcomes.

Despite the pervasiveness of the linkage research connecting service climate to customer reactions and financial outcomes, other important results have emerged from literature focusing on employee wellbeing and job-related outcomes. Yoon, Beatty and Suh (2001) found support for a positive relationship between service climate and work effort; this relation- ship, in turn, was positively related to job satisfaction. The Martin (2008) study reported that service climate is negatively related to job-induced tension and positively related to job satisfaction. Findings from the Babakus, Yavas, and Ashill (2009) article indicated the existence of a negative relationship between employees'customer orientation and employee levels of burnout. Finally, significant relationships between service climate and employee emotional exhaustion have been observed (Drach-Zahavy, 2010; Lam, Huang, \& Janssen, 2010). In consonance with the conservation of resources (COR) theory (Hobfoll, 1988, 1989), it is assumed that service climate is a source of resources for front-line employees (Lam et al., 2010) because their efforts related to interactions with customers are recognized.

\section{Dimensions of Service Climate}

Schneider et al. (1998; 2002) made an important attempt to delimitate the content of service climate more accurately and examine the interrelation among its facets. Schneider and colleagues observed the existence of four facets or dimensions of service climate: Global Service Climate, Customer Feedback, Customer Orientation, and Managerial Practices. Global Service Climate represents a general summary of the existing service climate in the organization. In contrast, the other three dimensions refer to specific service practices. Customer Feedback refers to the request and use of feedback by customers, Customer Orientation describes efforts to meet customer needs or expectations for service qualityand Managerial Practices reflect actions of immediate supervisors supporting and rewarding service quality efforts (Schneider et al., 1998). According to Schneider and colleagues (1998) the dimension of Global Service Climate was not a composite of the other three specific service climate dimensions, but insteadrepresented a different dimension describing the "molar" or general service climate. Schneider et al. (1998) examined the contribution of all three specific dimensions of service climate to the Global Service Climate dimension. They observed that all the specific dimensions were significantly related to Global Service Climate. Customer Orientation $(b=.54)$ and Managerial Practice $(b=.30)$ played a predominant role, while the contribution of Customer Feedback was secondary $(b=.10)$. This conceptualization and dimensionality of service climate has been well-recognized by the scientific community, making it possible to establish the different dimensions of service climate, as well as the nomological net within the construct (see Bagozzi, 1980), describing the contribution of specific service practices (Customer Orientation, Managerial Practices, and Customer Feedback) to the molar or general service climate concept (Global Service Climate). 


\section{The rationale of the current study}

Based on these previous research efforts by Schneider et al. $(1998 ; 2002)$, the current study aims to validate a measure of service climate in organizations in the Spanish language. This validation process has three steps.

First, confirmatory factor analyses (CFA) were used to test construct validity, while also considering scale convergent and discriminant validity. Construct validity is an attempt to establish whether the markers of a construct measure what they purport to measure (e.g., Babin, Boles, \& Robin, 2000). To this end, we evaluate the dimensionality of service climate. The four proposed dimensions of service climate (Global Service Climate, Customer Feedback, Customer Orientation, and Managerial Practices) are expected to show an adequate fit. In order to test this factorial structure more accurately, we compare the proposed four-factor model with two alternatives: a one-factor model (with all items loading in a single service climate factor) and a two-factor model (differentiating between Global Service Climate, on the one hand, and the rest of items loading in a factor of service practices, on the other). To reinforce the examination of construct validity, specific indicators of scale convergence and discriminant validity are also considered. Scale convergent validity is explored by examining the item-factor loadings and construct reliability estimates. Discriminant validity is evaluated by examining the correlations among service climate factors and the comparison between variance extracted estimates and the square of the correlation estimates between service climate factors.

Second, construct validity is also assessed by examining predictive or nomological validity. In order words, we assess whether service climate behaves as expected in terms of relationships, given our knowledge of the construct. This type of validity is important when the objective is to predict critical criteria (Nunnally, 1978). In our case, two considerations related to the predictive validity are made: a) relationships among service climate dimensions are examined; and b) associations between service climate and other constructs (service quality and burnout) are investigated. In congruence with the results observed by Schneider et al. (1998), the three specific service practices are expected to significantly contribute to the Global Service Climate. In addition, we expect significant links from service climate to service quality and burnout of employees. Service quality is surely the construct closest to service climate in nomological terms. In fact, the well-established linkage research (Dietz et al., 2004; Martínez-Tur et al., 2011) is based on the idea that service climate impacts on the service quality that employees deliver to customers. Both concepts (climate and quality) refer to the same object (service), and the perception of service climate by employees is easily translated into their service quality efforts in behavioural terms (e.g., efforts related to solving customer problems). Nevertheless, other effects of service climate, such as well-being at work, have been explored. Given the effort required in the attention to customers, service climate informs employees about whether their service quality efforts are recognized and supported. Thus, service climate can be considered as a direct precursor of well-being at work (Martin, 2008). Accordingly, we expect negative relationships between service climate and burnout. The consideration of service quality and burnout as criteria also allows further testing of convergent and discriminant validity. Since the "service quality" construct is the closest to the "service climate" construct, the magnitudes of the relationships are expected to be greater for service quality (convergent validity) than for burnout (discriminant validity).

Third, we examine whether service climate perceptions might be aggregated at the work-unit level. Many constructs in organizational research behave at different levels at the same time (Bliese, Chan, \& Ployhart, 2007). Climate is an illustrative example. Differences between individual perceptions provide information about "psychological climate". However, because employees in the same work-unit are subjected to similar processes and structures, they are able to develop shared perceptions of climate. Researchers refer to this collective reality as "organizational climate". Both psychological and organizational climates include the same content, but they describe different phenomena with different construct levels (see Kozlowski \& Klein, 2000). Similarly, we can observe individual (e.g., Martin, 2008) and collective approaches (Salanova et al., 2005) to service climate. In addition to individual differences, it is assumed that employees who pertain to the same work units (e.g., Hui et al., 2007) or branches (e.g., Schneider et al., 1998) develop consensual views about the importance attributed to service quality and the support for delivering good service to customers. With this in mind, we examine whether there is statistical justification for aggregating the service climate measure at the work-unit level.

\section{Method}

\section{Participants}

Data from two successive survey study projects were brought together. In previous research, the difficulty of having the necessary sample size to aggregate data at the work-unit level has been pointed out. For example, the study by Schneider et al. (1998, p. 156). was subjected to restrictions in the statistical analysis, given the obstacles to obtaining a large sample of work-units Combining data from two survey studies is useful for examining the validity of the service climate construct in the current study, as it allows us to have an adequate sample size at the individual and work-unit levels. Both 
research studies included the same items to measure service climate. The sites for this research were 120 hotels located on the Spanish Mediterranean Coast (Research Project I, N = 60; Research Project II, N = 60). Two types of work-units were considered: receptionists and waiters/waitresses. In general, they were working in hotels with a small number of employees. Employee surveys with missing data on any of the items considered in this research study were excluded from the final sample. Only work-units with at least 3 usable employee surveys were considered. This sampling plan resulted in a final sample of 152 work-units with 508 frontline employees, 267 working as receptionists $(52.6 \%)$ and 241 working as waiters or waitresses $(47.4 \%)$. Employees' average age was 33.6 years $(S D=$ $10.5)$, and about $49 \%$ of the participating employees were men. Position tenure ranged from a few months to 35.5 years, with an average of 6.6 years $(S D=8.6)$.

\section{Procedure}

Employee participation was anonymous and voluntary. For the data collection procedure, we used a "realtime approach" (Stewart \& Hull, 1992). Accordingly, the assessment occurs on-site and reflects a direct evaluation of perceptions and experiences related to the specific service delivered. All employees completed the survey administered by a researcher in the absence of managerial personnel. This procedure facilitated a high response rate (90\%). It included a phone-appointment with hotel managers to coordinate the first encounter with the employees who filled in the surveys during work-time at the hotel. To be eligible for this research study, employees had to interact face-to-face with customers as a critical part of their job requirements. In each work-unit, employees worked at the same level in the organizational hierarchy, they performed similar tasks, they had the same goals and the same supervisor, and they interacted with each other during their daily work.

\section{Measures}

Service Climate. Because content validity is a prerequisite for construct validity (Haynes, Richard, \& Kubany, 1995; Shipp, Burns, \& Desmul, 2010), a specific effort was made in the wording of the service climate items. A group of 6 researchers from three different universities located in Spain participated in a group discussion process. The concepts and scales developed by Schneider et al. (1998) served as the starting point, but adapting them to the Spanish language and the hospitality industry. In addition, the questionnaire had to have a manageable size to facilitate its implementation by hotel employees. During the group discussion process, different versions of items were analyzed.
Finally, the group of researchers agreed on the wording of the items used for this research study (see Table 1) to represent the domain implied in each of the four dimensions of service climate. Four items were written for each dimension. Items were scored on a 7-point scale $(1=$ completely disagree and $7=$ completely agree $)$.

Service Quality. To assess service quality, we used 12 items from the Spanish integrated measure of service quality (Sánchez-Hernández, Martínez-Tur, Peiró, \& Ramos, 2009). These 12 items were selected because they focused the attention on the direct interaction between employees and customers, maintaining concordance with service climate perceived by employees. A sample item is: "We (the employees) do more for the clients than normal". Low scores, ranging from 1 (totally disagree) to 7 (totally agree), are indicative of low service quality. For validation purposes, an average of the 12 items was considered (Cronbach alpha $=.87 ; M=5.9 ; S D=.68)$.

Burnout. To measure burnout, we used the Spanish adapted version (Schaufeli, Martínez, Marques Pinto, Salanova, \& Bakker, 2002) of the Maslach-Burnout Inventory-General Survey (Schaufeli, Leiter, Maslach \& Jackson, 1996). The instrument consisted of 10 items assessing the core of burnout: exhaustion (5 items, e.g., "I feel burned out by my work") and cynicism (5 items, e.g., "I have become more cynical about whether my work contributes anything"). Low scores on burnout, ranging from 0 (never) to 6 (always), are indicative of well-being at work. For validation purposes, an average of the 10 items was considered (Cronbach alpha $=.85 ; M=2.03 ; S D=1.2)$.

\section{Results}

\section{Dimensionality and scale convergent-discriminant validity}

Confirmatory factor analysis (CFA) was used to examine the dimensionality of service climate. Results used all 16 items of the Service Climate scale in the four latent variables which compose the service climate scale. As mentioned earlier, this model was compared to other two models: one where all items are included in a single factor, and the other one with 2 factors (one for Global Service Climate and the other for the rest of the dimensions). Analyses were computed using the program LISREL 8.80 (Jöreskog \& Sörbom, 1993) using correlation matrix and asymptotic covariance matrix as inputs and maximum likelihood as method of estimation. The calculation of indices supported the superiority of the proposed fourfactor model. The four-factor model differed from the two-factor model $\left(\mathrm{D} \chi^{2}=693.27\right.$; d.f. $\left.=5 ; p<.001\right)$ and the one-factor model $\left(\mathrm{D} \chi^{2}=872.6\right.$; d.f. $\left.=6 ; p<.001\right)$ (see Table 2). Loadings of the 4-factor model were all significant, taking into account their t-values. 
Table 1. Items for Service Climate

\begin{tabular}{|c|c|c|c|}
\hline \multicolumn{4}{|c|}{ Global Service Climate } \\
\hline & & $M$ & $S d$ \\
\hline $\begin{array}{l}\text { 1. Los empleados tienen las habilidades para } \\
\text { hacer un buen trabajo y ofrecer un servicio de } \\
\text { excelente calidad. }\end{array}$ & $\begin{array}{l}\text { Employees in our organization have knowledge } \\
\text { of the job and the skills to deliver superior qual- } \\
\text { ity work and service. }\end{array}$ & 5.53 & 1.49 \\
\hline $\begin{array}{l}\text { 2. Se reconoce y aprecia el trabajo bien hecho y } \\
\text { la prestación de un servicio de excelente cali- } \\
\text { dad. }\end{array}$ & $\begin{array}{l}\text { Employees receive recognition and rewards for } \\
\text { the delivery of superior work and service. }\end{array}$ & 5.06 & 1.69 \\
\hline $\begin{array}{l}\text { 3. El nivel de calidad de servicio que se ofrece } \\
\text { es excelente. }\end{array}$ & $\begin{array}{l}\text { The overall quality of service provided by our } \\
\text { organization to customers is excellent. }\end{array}$ & 5.04 & 1.55 \\
\hline $\begin{array}{l}\text { 4. Los empleados cuentan con los recursos para } \\
\text { hacer un buen trabajo y ofrecer un servicio de } \\
\text { excelente calidad. }\end{array}$ & $\begin{array}{l}\text { Employees are provided with tools, technology, } \\
\text { and other resources to support the delivery of } \\
\text { quality work and service. }\end{array}$ & 4.61 & 1.75 \\
\hline
\end{tabular}

Customer Feedback

5. Se pide la opinión a los clientes para evaluar la calidad del servicio.

6. Los empleados están informados de las opiniones de los clientes con respecto al servicio.

7. Los empleados están informados de las quejas de los clientes.

8. Se tienen en cuenta las opiniones y/o quejas de los clientes para mejorar.
Customers are asked their opinions in order to evaluate the service quality.

The employees are informed about the customers'opinions of service quality.

The employees are informed about customer complaints.

Customer's opinions and complaints are taken into account in an effort to improve.

\begin{tabular}{cc}
$M$ & $S d$ \\
\hline 5.42 & 1.70 \\
5.28 & 1.73
\end{tabular}

$5.73-1.55$

$5.66-1.55$

Customer Orientation
9. Se toman las decisiones considerando siempre al cliente.

10. Lo primero es satisfacer las necesidades y demandas de los clientes.

11. En este hotel, la satisfacción del cliente es lo más importante.

12. La dirección de este hotel da más importancia a la satisfacción de las necesidades de los clientes que a cualquier otro factor.
The decisions made always take the customer into consideration.

The most important thing is to fulfil the needs and requests of the customers.

In this hotel, customer satisfaction is of the utmost importance.

The management of this hotel gives more importance to satisfying customers' needs than to any other factor.

\section{Managerial Practices}

13. Mi jefe inmediato reconoce y aprecia el trabajo bien hecho y el servicio excelente.

14. Mi jefe inmediato está comprometido con la mejora del trabajo y del servicio.

15. Mi jefe inmediato nos motiva continuamente para realizar un buen trabajo y prestar un servicio excelente.

16. Mi jefe inmediato considera más importante presta un servicio de excelente calidad que cualquier cosa.
My immediate boss recognizes and appreciates a job well done and excellent service.

My immediate boss is committed to improving the work and the service.

My immediate boss constantly motivates us to do a good job and provide excellent service.

My immediate boss thinks providing excellent service quality is more important than anything else.

\begin{tabular}{cc}
$M$ & $S d$ \\
\hline 5.70 & 1.45 \\
5.77 & 1.39 \\
5.36 & 1.62 \\
& \\
5.60 & 1.40
\end{tabular}


Table 2. Fit statistics for structural models

\begin{tabular}{|c|c|c|c|c|c|c|c|c|}
\hline Model & $\chi^{2}$ & $\mathrm{df}$ & $\chi^{2 / d f}$ & RMSEA & GFI & IFI & CFI & NFI \\
\hline 4 factors & 325.33 & 98 & 3.31 & .07 & .85 & .99 & .99 & .98 \\
\hline 2 factors & 1018.6 & 103 & 9.88 & .13 & .65 & .94 & .94 & .93 \\
\hline 1 factor & 1197.93 & 104 & 11.51 & .14 & .62 & .93 & .93 & .92 \\
\hline \multicolumn{3}{|c|}{ Cut-off values } & $<.05$ & $<.08$ & $>.90$ & $>.90$ & $>.90$ & $>.90$ \\
\hline
\end{tabular}

Note . RMSEA = Root Mean Square Error of Approximation; GFI = Goodness-of-fit index; CFI = Comparative Fit Index; IFI= Incremental fit index; NFI = Normed fit index .

Item-factor loadings and construct reliability estimates indicated adequate scale convergent validity (see Table 3). Construct reliability estimates also confirmed adequate scale convergence validity, ranging from .83 to .90 . Item-factor loadings were substantial (> .70, see Shipp et al., 2010), ranging from .71 to .94 . All of them were highly significant $(p<.001)$, suggesting scale convergence (Anderson \& Gerbing, 1988) (see Table 3). In addition, the results suggested adequate scale discriminant validity. None of the correlations among service climate factors was greater than .85 (range .48 to .61 , see Table 4 ), thus providing evidence for discriminant validity (see Shipp et al., 2010). All variance-extracted estimates are greater than the square of the correlation estimates between factors, reinforcing discriminant validity (Babin et al., 2000; Fornell \& Lacker, 1981).

\section{Predictive Validity}

We regressed the dimension of Global Service Climate on the three specific service climate dimensions to determine the contribution of specific to the global one. As expected, the results revealed that Global Service Climate was significantly related to each of the three specific dimensions of service climate $\left.F(3.507)=128.37, p=.001, \mathrm{R}^{2}=.43\right)$, Customer Orientation $(b=.34, p<.001)$; Customer Feedback $(b=.12, p<.005)$ and Managerial Practices $(b=.35$, $p<.001)$.

Correlations between service climate, burnout, and service quality are shown in Table 4 . Correlations with service climate are greater for service quality than for burnout, indicating convergent and discriminant validity.

Table 3. Standardized Confirmatory Factor Analysis (CFA) loading estimates, variance extracted and reliability

\begin{tabular}{llc}
\hline Item Description & Global Customer Customer Managerial \\
& Service & Feedback Orientation Practices \\
& Climate & \\
\end{tabular}

1. Employees in our organization have knowledge of the job and the skills to deliver superior quality work and service.

2. Employees receive recognition and rewards for the delivery of superior work and service.

.71

.79

. The overall quality of service provided by our organization to customers is excellent.

4. Employees are provided with tools, technology, and other resources to support the delivery of quality work and service.

5. Customers are asked their opinions in order to evaluate the service quality. $\quad .72$

6. The employees are informed about customers' opinions of the service quality.

7. The employees are informed about customer complaints.

8. Customers' opinions and complaints are taken into account in an effort to improve.

9. The decisions made always take the customer into consideration.

10. The most important thing is to fulfil the needs and requests of the customers.

11. In this hotel, customer satisfaction is of the utmost importance.

12. The management of this hotel gives more importance to satisfying customers' needs than to any other factor.

13. My immediate boss recognizes and appreciates a job well done and excellent service.

14. My immediate boss is committed to improving the work and the service.

15. My immediate boss constantly motivates us to do a good job and provide excellent service.

16. My immediate boss thinks providing excellent service quality is more important than anything else.

.75

.83

.78

Variance extracted

Variance extr
Reliability

.59

.83 
Table 4. Correlations between Service Climate full scale,Service Climate factors, burnout and Performance

\begin{tabular}{|c|c|c|c|c|c|c|}
\hline Factor & $\begin{array}{c}\text { Service } \\
\text { Climate } \\
\text { full scale }\end{array}$ & $\begin{array}{l}\text { Global } \\
\text { Service } \\
\text { Climate }\end{array}$ & $\begin{array}{l}\text { Customer } \\
\text { Feedback }\end{array}$ & $\begin{array}{l}\text { Customer } \\
\text { Orientation }\end{array}$ & $\begin{array}{c}\text { Managerial } \\
\text { Practices }\end{array}$ & Burnout \\
\hline Global Service Climate & $.81 * *$ & - & & & & \\
\hline Customer Feedback & $\begin{array}{c}.80 * * \\
(.24)\end{array}$ & $.48^{* *}$ & - & & & \\
\hline Customer Orientation & $\begin{array}{l}.84 * * \\
(.34)\end{array}$ & $\begin{array}{l}.58 * * \\
(.38)\end{array}$ & $.61 * *$ & - & & \\
\hline Managerial Support & $\begin{array}{l}.83 * * \\
(.35)\end{array}$ & $\begin{array}{l}.59 * * \\
(.28)\end{array}$ & $\begin{array}{l}.53 * * \\
(.37)\end{array}$ & $.61 * *$ & - & \\
\hline Burnout & $-.37 * *$ & $-.38 * *$ & $-.26 * *$ & $-.26 * *$ & $-.31 * *$ & - \\
\hline Service Quality & $.59 * *$ & $.53^{* *}$ & $.41 * *$ & $.51 * *$ & $.51 * *$ & $-.30 * *$ \\
\hline
\end{tabular}

Note: In brackets the square of the correlation estimates between factors.

All correlations are significant $* * p<.01$.

\section{Justification for aggregation}

In addition to differences between individuals in their perception of service climate (psychological climate), it is generally assumed that work-units are able to develop shared perceptions (organizational service climate). To analyze the within-group agreement and between-group differentiation, we calculated interrater agreement indexesr $_{\mathrm{wg}(\mathrm{J})}$ (James, Demaree, \& Wolf, 1984), an average deviation index based on the deviation from the item mean $\mathrm{AD}_{\mathrm{M}(\mathrm{J})}$ (Burke, Finkelstein, \& Dusig, 1999; Dunlap, Burke, \& Smith-Crowe, 2003), and ICC(1) and ICC(2) (James, 1982) (see Table 5). The ICC(1) represents both the reliability and the degree to which group members' responses are influenced by group membership, whereas the ICC(2) indicates whether groups can be reliably differentiated based on the variable of interest (Bliese, 2000).

In general, the aggregation at the work-unit level was statistically supported (see Table 5), with a range of 26\% (Global Service Climate) to $15 \%$ (Managerial Practices) of variance in individual perceptions explained by work-unit membership. Finally, one-way analysis of variance (ANOVA) indicated that work- units differed significantly in their employee perceptions of each dimension of service climate, Service Climate full scale $F(150,357)=2.44, p<.001$, Global Service Climate $F(150,357)=2.51, p<.001$, Cus-tomer Feedback $F(150,357)=2.19, p<.001$, Customer Orientation $F(150,357)=2.02, p<.000$, and Managerial Practices $F(150,357)=2.047, p<.001$.

\section{Discussion}

The objective of the current study was to describe and validate a measure of service climate in the Spanish language. Based on the concepts and scales developed by Schneider et al. $(1998 ; 2002)$, a group of 6 researchers from 3 different universities in Spain designed scales to assess the four dimensions of service climate: Global Service Climate, Customer Feedback, Customer Orientation and Managerial Practices. Our results confirmed adequate construct validity. The measure showed a good differentiation of the four expected dimensions. We observed satisfactory indicators of convergent and discriminant validity, and predictive validity was congruent with previous kno-

Table 5. Aggregation indexes for Service Climate scale and dimensions

\begin{tabular}{|c|c|c|c|c|}
\hline Variable & $\mathrm{r}_{\mathrm{wg}(\mathrm{J})}$ & $\mathrm{AD}_{\mathrm{M}(\mathrm{J})}$ & ICC $[1]$ & $\mathrm{ICC}[2]$ \\
\hline Service Climate full scale & .89 & 1.13 & .23 & .61 \\
\hline Global Service Climate & .73 & 1.28 & .26 & .65 \\
\hline Customer Feedback & .68 & 1.20 & .21 & .58 \\
\hline Customer Orientation & .80 & .96 & .18 & .54 \\
\hline Managerial Practices & .76 & 1.07 & .15 & .49 \\
\hline Cut-off values & $<1.17$ & $<1.52$ & $0.00-0.50$ & $>.70$ \\
\hline
\end{tabular}

Note. $\mathrm{r}_{\mathrm{wg}(\mathrm{J}),}$ (James et al.,1984); $\mathrm{ADI}_{\mathrm{M}(\mathrm{J})}$, (Burke et al., 1999, Dunlap et al.,2003); ICC[1] and ICC2, (Bliese, 2000, James, 1982). 
wledge about the behaviour of the construct. Finally, we found statistical justification to aggregate service climate at the work-unit level with this measure, supporting the idea that service climate is not only an individual reality but also a collective phenomenon.

When measures are designed for a specific language, a systematic effort is required. In our case, the starting point was the research findings of Schneider et al. $(1998 ; 2002)$, but a process of designand validation of the measures was implemented. In addition to a detailed wording in Spanish covering the different dimensions of service climate (content validity) (Haynes et al., 1995; Shippet al., 2010), different steps were taken to examine the construct validity. First, our measure is able to differentiate the four aforementioned service climate dimensions. One of the main problems associated with self-report measures is the potential existence of common method variance (Kemery \& Dunlap, 1986; Lindell \& Whitney, 2001). Because the same person usually answers all the items, relations among variables may be artificially inflated. In other words, participants do not distinguish among different variables and dimensions. Our findings demonstrated that common method variance is not a generalized problem associated with the use of the service climate measure. If common method variance were operating, we would expect a single factor to better explain the structure of our measure. However, confirmatory factor analysis confirmed the superiority of the expected four-factor model (see Podsakoff, MacKenzie, Lee, \& Podsakoff, 2003). Therefore, the conclusion can be drawn that the measure is able to evaluate the service climate dimensions in a differentiated manner. The indicators obtained describe adequate scale convergent and discriminant validity, reinforcing this argument.

Second, we examined predictive validity, which is a critical test to explore the validity of the construct. In the nomological net, the operationalization is expected to behave according to the knowledge researchers have of the construct in relationship terms (e.g., Dries, Pepermans, \& Carlier, 2008). If this is not the case, it is very difficult to accept that the measure really refers to the construct it aims to assess. Our measure demonstrated predictive validity in two directions. Internally, the different facets of service climate are interrelated, in consonance with previous research efforts. As in the investigation by Schneider et al. (1998), all specific service practices contributed to Global Service Climate, with a secondary role of Customer Feedback. In addition, predictive validity is satisfactory when other external constructs are considered. As expected, our measure presented stronger relationships with the closest construct to service climate in its nomological net (service quality), better than the relationship with the other more distant construct (burnout). In sum, our measure is capable of behaving as expected in nomo- logical terms, reflecting the construct we aim to evaluate.

Third, we examined the degree to which aggregation of service climate is statistically justified. In addition to individual perceptions of service climate, it is generally assumed that employees of work-units are able to share service climate perceptions (e.g., Hui et al., 2007). Accordingly, our measure was examined in order to test whether it has the ability to reflect this typical consensual view existing in work-units. Statistical indicators confirmed the existence of shared perceptions of service climate.

As in all studies, the present one has some limitations that should be noted. First, the description and validation of our service climate measure was restricted to the context of hotels in Spain. Thus, generalization is somewhat limited. It may be useful to include other types of samples, each representing a different service sector, in order to increase the generalization of the measure. Second, although we present a test of the predictive validity, more efforts are needed in order to incorporate additional constructs in an extended nomological net corresponding to service climate. In this endeavour, other sources of data (e.g., customers, supervisors) could be incorporated to obtain a more solid test of the predictive power of the measure, and objective indicators (e.g., financial outcomes) could also be considered. Our measures were obtained via questionnaires and so results could be somewhat inflated by self-report bias. Future studies should be conducted with non-self-report measures. Finally, future research studies could extend the level of construct and analysis, considering the branch as a whole. In previous research studies (e.g., Schneider et al., 2002), it was assumed that the employees of a branch are able to develop shared perceptions of service climate. It would be interesting to examine the degree to which our measure is able to reflect this peculiarity of service climate.

In spite of its limitations, this instrument makes it possible to evaluate the four-factor model of service climate accurately. In addition, the measure behaves as expected in the nomological net. Finally, it is able to reflect the collective nature of service climate beyond the individual level. In sum, the current research study offers a measure of service climate in the Spanish language with adequate validity.

\section{References}

Anderson, J. C., \& Gerbing, D. W. (1988). Structural equation modeling in practice: A review and recommended two-step approach. Psychological Bulletin, 103, 411-423.

Ashkanasy, N. M., Wilderom, C. P. M., \& Peterson, M. (2000). Handbook of organisational culture and climate. SAGE, Thousand Oaks.

Babakus, E., Yavas, U., \& Ashill, N. J. (2009). The role of 
customer orientation as a moderator of the job de-mandburnout-performance relationship: A surface-level trait perspective. Journal of Retailing, 85, 480-492.

Babin, B. J., Boles, J. S., \& Robin, D. P. (2000). Representing the perceived ethical climate among marketing employees. Journal of the Academy of Marketing Science, 28, 345-358.

Bagozzi, R. P. (1980). Causal modeling in marketing. New York: John Wiley.

Barker, R. G. (1965). Explorations in ecological psychology. American Psychologist, 20, 1-14.

Bliese, P. D. (2000). Within-group agreement, non-independence, and reliability: Implications for data aggregation and analysis. In K. J. Klein \& S. W. J. Kozlowski (Eds.), Multilevel theory, research, and methods in organizations: Foundations, extensions, and new directions. (pp. 349-381). San Francisco, CA, US: Jossey-Bass.

Bliese, P. D., Chan, D., \& Ployhart, R. E. (2007). Multilevel methods: Future directions in measurement, longitudinal analyses, and non-normal outcomes. Organizational Research Methods, 10, 551-563.

Borucki, C. C., \& Burke, M. J. (1999). An examination of service-related antecedents to retail store performance. Journal of Organizational Behavior, 20, 943-962.

Burke, M. J., Finkelstein, L. M., \& Dusig, M. S. (1999). On average deviation indices for estimating interrater agreement. Organizational Research Methods, 2, 49-68.

Campbell, J. J., Dunnette, M. D., Lawler, E. E., \& Weick, K. E. (1970). Managerial behavior, performance, and effectiveness. New York, NY, US: McGraw-Hill.

Day, D. V., \& Bedeian, A. G. (1995). Personality similarity and work-related outcomes among African-American nursing personnel: A test of the supplementary model of person-environment congruence. Journal of Vocational Behavior, 46, 55-70.

Denison, D. R. (1996). What is the difference between organizational culture and organizational climate? A native's point of view on a decade of paradigm wars. The Academy of Management Review, 21, 619-654.

Dietz, J., Pugh, S. D., \& Wiley, J. W. (2004). Service climate effects on customer attitudes: An examination of boundary conditions. Academy of Management Journal, 47, 8192.

Drach-Zahavy, A. (2010). How does service workers' behavior affect their health? Service climate as a moderator in the service behavior-health relationships. Journal of Occupational Health Psychology, 15, 105-119.

Dries, N., Pepermans, R. M., \& Carlier, O. (2008). Career success: Constructing a multidimensional model. Journal of Vocational Behavior, 73, 254-267.

Dunlap, W. P., Burke, M. J., \& Smith-Crowe, K. (2003). Accurate tests of statistical significance for $r_{\mathrm{WG}}$ and average deviation interrater agreement indexes. Journal of Applied Psychology, 88, 356-362.

Fornell, C. D., \& Lacker, D. F. (1981). Evaluating structural equation models with unobservable variables and measurement error. Journal of Marketing Research, 18, 39-50.

Haynes, S. N., Richard, D. C. S., \& Kubany, E. S. (1995).
Content validity in psychological assessm ent. Psychological Assessment, 7, 238-247.

Hellriegel, D., \& Slocum, J. W. (1974). Organizational climate: Measures, research and contingencies. Academy of Management Journal, 17, 255-280.

Hobfoll, S. E. (1988). The ecology of stress. New York, NY: Hemisphere.

Hobfoll, S. E. (1989). Conservation of resources: A new attempt at conceptualizing stress. American Psychologist, 44, 513-524.

Hui, C. H., Chiu, W. C. K., Yu, P. L. H., Cheng, K., \& Tse, H. H. M. (2007). The effects of service climate and the effective leadership behaviour of supervisors on frontline employee service quality: A multi-level analysis. Journal of Occupational and Organizational Psychology, 80, 151172.

James, L. R. (1982). Aggregation bias in estimates of perceptual agreement. Journal of Applied Psychology, 67, 219-229.

James, L. R., Choi, C. C., Ko, C. H. E., McNeil, P. K., Minton, M. K., \& Wright, M. A. (2008). Organizational and psychological climate: A review of theory and research. European Journal of Work and Organizational Psychology, 17, 5-32.

James, L. R., Demaree, R. G., \& Wolf, G. (1984). Estimating within-group interrater reliability with and without response bias. Journal of Applied Psychology, 69, 85-98.

James, L. R., James, L. A., \& Ashe, D. (1990). The meaning of organizations: The role of cognition and values. In B. Schneider (Ed.), Organizational Climate and Culture (pp. 40-84). San Francisco: Jossey-Bass.

James, L. R., \& Jones, A. P. (1974). Organizational climate: A review of theory and research. Psychological Bulletin, 81, 1096-1112.

Johnson, J. W. (1996). Linking employee perceptions of service climate to customer satisfaction. Personnel Psycho$\log y, 49,831-851$.

Jones, A. P., \& James, L. R. (1979). Psychological climate: Dimensions and relationships of individual and aggregated work environment perceptions. Organizational Behavior \& Human Performance, 23, 201-250.

Jöreskog, K. G., \& Sörbom, D. (1993). LISREL 8: Structural equation modeling with the SIMPLIS command language. Chicago: Scientific Software.

Kemery, E. R., \& Dunlap, W. P. (1986). Partialling factor scores does not control method variance: A reply to Podsakoff and Todor. Journal of Management, 12, 525530.

Kozlowski, S. W. J., \& Klein, K. J. (2000). A multilevel approach to theory and research in organizations: Contextual, temporal, and emergent processes. In K. J. Klein \& S. W. J. Kozlowski (Eds.), Multilevel theory, research, and methods in organizations: Foundations, extensions, and new directions (pp. 3-90). San Francisco, CA, US: Jossey-Bass.

Lam, C. K., Huang, X., \& Janssen, O. (2010).Con textualizing emotional exhaustion and positive emotional display: The signaling effects of supervisors' emotional exhaus- 
tion and service climate. Journal of Applied Psychology, 95, 368-376.

Leung, K. (1997). Relationships among satisfaction, commitment, and performance: A group-level analysis. Applied Psychology: An International Review, 46, 199-206.

Lewin, K. (1951). Field theory in social science: Selected theoretical papers (edited by Dorwin Cartwright). Oxford, England: Harpers.

Lewin, K., Lippit, R., \& White, R. K. (1939). Patterns of aggressive behavior in experimentally created social climates. Journal of Social Psychology, 10, 271-299.

Likert, R. (1961). New patterns of management. New York, NY, US: McGraw-Hill.

Likert, R. (1967). The human organization: Its management and values. New York, NY, US: McGraw-Hill.

Lindell, M. K., \& Whitney, D. J. (2001). Accounting for common method variance in cross-sectional research designs. Journal of Applied Psychology, 86, 114-121.

Litwin, G. H., \& Stringer, R. A., Jr. (1968). Motivation and organizational climate. Oxford, England: Harvard U., Graduate School of Business Administration.

Martin, A. (2008). Service climate and employee well being in higher education. Journal of Management \& Organization, 14, 155-167.

Martínez-Tur, V., Tordera, N., Peiró, J. M., \& Potocnik, K. (2011). Linking service climate and disconfirmation of expectations of customer satisfaction: A cross-level study. Journal of Applied Social Psychology, 41, 1189-1213.

Nunnally, J. C. (1978). Psychometric theory. NewYork: McGraw-Hill.

Osgood, C. E., Suci, G. J., \& Tannenbaum, P. H. (1957). The measurement of meaning. Oxford, England: Univer. Illinois Press.

Parkington, J. J., \& Schneider, B. (1979). Some correlates of experienced job stress: A boundary role study. The Academy of Management Journal, 22, 270-281.

Payne, R. L., \& Pugh, D. S. (1976). Organizational structure and climate.In M.D. Dunnette (Ed.), Handbook of Industrial and Organizational Psychology (pp. 1125-1173). Chicago: Rand McNally.

Podsakoff, P. M., MacKenzie, S. B., Lee, J., \& Podsakoff, N. P. (2003). Common method biases in behavioral research: A critical review of the literature and recommended remedies. Journal of Applied Psychology, 88, 879-903.

Rousseau, D. M. (1988). The construction of climate in organizational research. In C. L. Cooper, \& I. T. Robertson (Eds.), International review of industrial and organizational psychology (pp. 139-158). Oxford, England: John Wiley \& Sons.

Rucci, A. J., Kirn, S. P., \& Quinn, R. T. (1998). The employee-customer-profit chain at sears. Harvard Business Review, 83-97.

Salanova, M., Agut, S., \& Peiró, J. M. (2005). Linking organizational resources and work engagement to employee performance and customer loyalty: The mediation of service climate. Journal of Applied Psychology, 90, 12171227.

Sánchez-Hernández, R., Martínez-Tur, V., Peiró, J. M., \&
Ramos, J. (2009). Testing a hierarchical and integrated model of quality in the service sector: Functional, relational, and tangible dimensions. Total Quality Management \& Business Excellence, 20, 1173-1188.

Schaufeli, W. B., Leiter, M. P., Maslach, C., \& Jackson, S. E. (1996). The Maslach burnout inventory-general survey.In C. Maslach, S. E. Jackson, \& M. P. Leiter (Eds.), Maslach Burnout Inventory Manual (3rd ed). Palo Alto, CA: Consulting Psychologists Press.

Schaufeli, W. B., Martínez, I. M., Marques Pinto, A., Salanova, M., \& Bakker, A. B. (2002). Burnout and engagement in university students: A cross-national study. Journal of Cross-Cultural Psychology, 33, 464-481.

Schneider, B. (1973). The perception of organizational climate: The customer's view. Journal of Applied Psychology, 57, 248-256.

Schneider, B. (1980). The service organization: Climate is crucial. Organizational Dynamics, 9, 52-65.

Schneider, B., \& Bowen, D. E. (1985). Employee and customer perceptions of service in banks: Replication and extension. Journal of Applied Psychology, 70, 423-433.

Schneider, B., \& Bowen, D. (1995). Winning the service game. Boston: Harvard Business School Press.

Schneider, B., Bowen, D. E., Ehrhart, M. G., \& Holcombe, K. M. (2000). The climate for service: Evolution of a construct. In Ashkanasy, C. Wilderom, \& M.F. Peterson (Eds.). Handbook of Organizational Culture and Climate (pp. 21-36). Thousand Oaks, CA: Sage.

Schneider, B., Ehrhart, M. G., Mayer, D. M., Saltz, J. L., \& Niles-Jolly, K. (2005). Understanding organization-customer links in service settings. Academy of Management Journal, 48, 1017-1032.

Schneider, B., Salvaggio, A. N., \& Subirats, M. (2002). Climate strength: A new direction for climate research. Journal of Applied Psychology, 87, 220-229.

Schneider, B., Wheeler, J. K., \& Cox, J. F. (1992). A passion for service: Using content analysis to explicate service climate themes. Journal of Applied Psychology, 77, 705716.

Schneider, B., White, S. S., \& Paul, M. C. (1998). Linking service climate and customer perceptions of service quality: Tests of a causal model. Journal of Applied Psychology, 83, 150-163.

Shaver, K. G. (1987). Principles of social psychology (3rd ed.). Hillsdale, NJ, England: Lawrence Erlbaum Associates, Inc.

Shipp, F., Burns, G. L., \& Desmul, C. (2010). Construct validity of ADHD-IN, ADHD-HI, ODD toward adults, academic and social competence dimensions with teacher ratings of Thai adolescents: Additional validity for the child and adolescent disruptive behavior inventory. Journal of Psychopathology Behavior Assessment, 32, 557-564.

Stewart, W. P., \& Hull, R. B. (1992). Satisfaction of what? post hoc versus real-time construct validity. Leisure Sciences, 14, 195-209.8

Tagiuri, R., \& Litwin, G. H. (1968). Organizational climate: Explorations of a concept. Boston: Jarvard Business School, Division of Research. 
Wiley, J. W. (1996). Linking survey data to the bottom line. In A. I. Kraut (Ed.), Organizational Surveys. Tools for Assessment and Change (pp. 330-359). San Francisco: Jossey-Bass.
Yoon, M. H., Beatty, S. H., \& Suh, J. (2001). The effect of work climate on critical employee and customer outcomes: An employee-level analysis. International Journal of Service Industry Management, 12, 500-521.

Manuscript received: 30/05/2012 Revision Received: 27/07/2012

Accepted: 27/07/2012 